\begin{tabular}{|c|c|c|}
\hline & $\begin{array}{c}\text { Gazi University } \\
\text { Journal of Science }\end{array}$ & 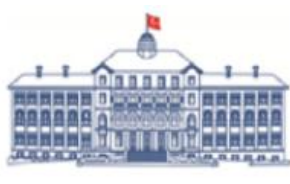 \\
\hline & http://dergipark.gov.tr/gujs & \\
\hline
\end{tabular}

\title{
3PL Service Provider Selection with a Goal Programming Model Supported with Multicriteria Decision Making Approaches
}

\author{
Evrencan OZCAN*(D), Merve AHISKALI \\ Kırlkkale University, Faculty of Engineering, Department of Industrial Engineering, 71451, Kırlkkale, Turkey
}

\author{
Highlights \\ - This paper focuses on 3PL service provider selection problem for a foreign trade company. \\ - A hybrid model is proposed for the best 3PL service provider-order combination. \\ - It's the first for multimodal international transport with consistent results for relevant problem.
}

\begin{tabular}{l} 
Article Info \\
\hline \\
Received: $10 / 04 / 2019$ \\
Accepted: $01 / 11 / 2019$ \\
Keywords \\
\hline 3PL Service Provider \\
Selection \\
Goal Programming \\
AHP \\
TOPSIS
\end{tabular}

\section{INTRODUCTION}

The average share of logistics costs (transportation cost, storage cost, inventory cost, order processing cost, procurement, handling, distribution and disposal cost, and customer service expenses [1]) in gross domestic product (GDP) varies 13\% in India, 9\% in the United States, $10 \%$ in the European Union, $11 \%$ in Japan, $18 \%$ in China, and 16\% in Thailand. The fact that logistics costs / GDP ratio is high is seen as a negative situation for the countries' economy. For example, low-level transport infrastructure and logistics service quality increase logistics costs in India. This situation affects the competitive power of the countries negatively in global markets [2]. The level of impact of these important complements of activities, which affect the positions of countries in the global world, is thereby high in enterprises, too. In addition to this, many factors such as globalization, institutional structuring, additional space requirements, changes in logistics management, and labor problems increase the interest in logistics outsourcing. Therefore today, many enterprises focus on their core competencies and direct their logistics functions to 3PL service providers. The outsourcing of logistics activities has made it a necessity to effectively select 3PL service providers [3].

\begin{abstract}
In this study, third-party logistics (3PL) service provider selection problem is handled for a and who has problems regarding both cost, delivery quality and delivery time. In this direction, 7 criteria are determined for effective evaluation of the performance of the 5 logistics service provider according to the property of the orders (quantity, mode of conveyance, transportation channel, etc.). The priority levels of service providers are calculated by using these criteria in the combination of Analytic Hierarchy Process (AHP), and Technique for Order Preference by Similarity to Ideal Solution (TOPSIS). Then, a goal programming (GP) model that answers the and the 12 system constraints and 5 objectives that the company encountered in real life is proposed. This model is the first one proposed in the literature for the selection of 3PL service providers for multimodal international transport with consistent results. The model is solved for service provider combination is obtained. As a result of the solution of the problem with this methodology, an improvement is achieved about $7 \%$ for the rate of delivery on time, $33 \%$ for bid - bill consistency rate, and $29 \%$ for the problematic delivery rate.
\end{abstract}


3PL service provider selection is a complex multi-criteria decision-making problem that attempts to optimize more than one objective simultaneously like quality, cost and delivery time. This multi-objective and multi-criteria structure of the problem makes it difficult for decision-makers to work on the problem which have critical importance for the companies and thereby countries [4]. The importance of the issue has necessitated the resolution of the problem despite the complexity of its structure and led the researchers to focus on the selection of the most appropriate 3PL service provider, especially in the last 15 years. Therefore, it is possible to find many studies about the selection of 3PL service provider in the literature. In most studies, selection is made using multi-criteria decision-making (MCDM) techniques such as AHP [5-12], Analytic Network Process (ANP) [13,14], TOPSIS [15], Elimination and Choice Translating Reality (ELECTRE) [3,16] and The Decision Making Trial and Evaluation Laboratory (DEMATEL) [17] or their fuzzy forms [18-24]. In addition, heuristics [25] and statistical methods [26] are also available. Mathematical models $[25,27,28]$ are rarely used to solve the problem. In addition, there are also hybrid models [29-35] in which these approaches are used together. In this context, some examples of studies about the 3PL service provider selection problem as a result of reviewing made on databases such as Science Direct, IEEE, Emerald, Ebsco, Springer and Taylor \& Francis are given in Table 1.

Table 1. Literature overview

\begin{tabular}{|c|c|c|}
\hline Researchers & Methods & $\begin{array}{c}\text { Criteria/Objectives } \\
\end{array}$ \\
\hline $\begin{array}{c}\text { Kulak, } \\
\text { Kahraman [18] }\end{array}$ & Fuzzy AHP & $\begin{array}{c}\text { Transportation cost, error rate, delay rate, flexibility, } \\
\text { documentability }\end{array}$ \\
\hline $\begin{array}{l}\text { Aguezzoul et } \\
\text { al. [16] }\end{array}$ & ELECTRE & $\begin{array}{l}\text { Service charge, quality control, firm culture, firm size, on-time } \\
\text { delivery, service area, computing performance }\end{array}$ \\
\hline $\begin{array}{l}\text { Bottani, Rizzi } \\
\quad[19]\end{array}$ & Fuzzy TOPSIS & $\begin{array}{l}\text { Service width, experience, service classification, compliance, } \\
\text { financial stability, service flexibility, performance, cost, physical } \\
\text { need and knowledge, quality, strategic attitude, trust and honesty }\end{array}$ \\
\hline $\begin{array}{l}\text { Jharkharia, } \\
\text { Shankar [13] }\end{array}$ & ANP & $\begin{array}{c}\text { Long-term operational performance, financial position, risk } \\
\text { management }\end{array}$ \\
\hline $\begin{array}{l}\text { Qureshi vd. } \\
\quad[15]\end{array}$ & $\begin{array}{l}\text { TOPSIS \& } \\
\text { Interval Data }\end{array}$ & $\begin{array}{c}\text { Capacity, flexibility, quality management, financial stability, } \\
\text { compliance, reputation, long-term relationship, balance capacity, } \\
\text { business value, service ratio and geographic availability }\end{array}$ \\
\hline Göl et al. [5] & AHP & $\begin{array}{c}\text { General company evaluation, capacity, quality, customer } \\
\text { relations, employee relations }\end{array}$ \\
\hline $\begin{array}{l}\text { Kasture vd. } \\
{[20]}\end{array}$ & $\begin{array}{l}\text { AHP \& Fuzzy } \\
\text { Set Theory }\end{array}$ & $\begin{array}{l}\text { Logistics capacity, logistic service quality, logistic information } \\
\text { capacity, potential growth, flexibility }\end{array}$ \\
\hline Çakır et al. & Fuzzy TOPSIS & $\begin{array}{l}\text { Service cost, financial performance, operational performance, } \\
\text { 3PL image, long term relationship }\end{array}$ \\
\hline Perçin [29] & AHP \& TOPSIS & Strategic factors, business factors, risk factors \\
\hline $\begin{array}{l}\text { Chiang ve } \\
\text { Tzeng [22] }\end{array}$ & Fuzzy AHP & $\begin{array}{c}\text { Price, delivery performance, information technology, flexibility } \\
\text { to respond to specific orders }\end{array}$ \\
\hline Soh $[6]$ & AHP & Finance, service level, relationships, management, infrastructure \\
\hline $\begin{array}{l}\text { Vijayvargiya, } \\
\text { Dey [7] }\end{array}$ & AHP & Cost, delivery, cost of additional services \\
\hline $\begin{array}{c}\text { Barker, } \\
\text { Zabinsky [8] }\end{array}$ & AHP & $\begin{array}{l}\text { Costs (recovered material, test costs, scrap), business relations } \\
\text { (property information, customer relations) }\end{array}$ \\
\hline $\begin{array}{l}\text { Özbek, Eren } \\
{[14]}\end{array}$ & ANP & $\begin{array}{l}\text { Quality, long-term relationship, firm image, operational } \\
\text { performance }\end{array}$ \\
\hline Daim et al. [9] & AHP & $\begin{array}{c}\text { Cost, service quality, information technology, industry } \\
\text { experience, local presence }\end{array}$ \\
\hline $\begin{array}{l}\text { Hwang, Chen } \\
\text { [10] }\end{array}$ & AHP & $\begin{array}{c}\text { Service, performance, cost, quality assurance, information } \\
\text { technology }\end{array}$ \\
\hline $\begin{array}{l}\text { Sharma, } \\
\text { Kumar [26] }\end{array}$ & $\begin{array}{l}\text { Quality } \\
\text { Function } \\
\text { Deployment }\end{array}$ & $\begin{array}{l}\text { Wage, industry experience, on-time delivery, assets, capacity } \\
\text { utilization, logistics information system, technical integration, } \\
\text { optimization capacity, financial growth rate, customer impact, }\end{array}$ \\
\hline
\end{tabular}




\begin{tabular}{|c|c|c|}
\hline & $\begin{array}{c}\text { (QFD) \& } \\
\text { Taguchi Loss } \\
\text { Function }\end{array}$ & $\begin{array}{l}\text { international scope, ability to meet specific requirements, } \\
\text { responsiveness, management level, overall image }\end{array}$ \\
\hline $\begin{array}{l}\text { Yayla et al. } \\
{[23]}\end{array}$ & Fuzzy AHP & $\begin{array}{c}\text { Sustainable relationship, service quality, continuous } \\
\text { development }\end{array}$ \\
\hline $\begin{array}{c}\text { Gürcan et al. } \\
{[11]}\end{array}$ & AHP & $\begin{array}{c}\text { Compliance, long term relationship, financial position, firm } \\
\text { image }\end{array}$ \\
\hline $\begin{array}{l}\text { Govindan et al. } \\
\text { [17] }\end{array}$ & $\begin{array}{c}\text { Grey } \\
\text { DEMATEL }\end{array}$ & $\begin{array}{c}\text { Service quality, on-time delivery, flexibility in operation, service } \\
\text { cost, customer service, logistics information system, financial } \\
\text { balance, image, geographic location, technical capacity, } \\
\text { performance history, human resources policies }\end{array}$ \\
\hline Raut et al. [30] & $\begin{array}{l}\text { Data } \\
\text { Envelopment } \\
\text { Analysis \& } \\
\text { ANP } \\
\end{array}$ & $\begin{array}{l}\text { Transport fee, fleet capacity, vehicle shape and quality, drive } \\
\text { effect, performance, timely transport of vehicles }\end{array}$ \\
\hline Bianchini [31] & AHP \& TOPSIS & $\begin{array}{l}\text { Cost, service level, professionalism, geographic location, } \\
\text { experience, innovation capacity and cooperation with customers }\end{array}$ \\
\hline $\begin{array}{l}\text { Aguezzoul, } \\
\text { Pires [3] }\end{array}$ & ELECTRE I & Service, location, information systems, quality \\
\hline $\begin{array}{l}\text { Singh et al. } \\
\text { [35] }\end{array}$ & $\begin{array}{l}\text { Fuzzy AHP \& } \\
\text { Fuzzy TOPSIS }\end{array}$ & $\begin{array}{c}\text { Transportation and storage costs, logistics infrastructure and } \\
\text { storage adequacy, customer service, material loading capacity, } \\
\text { quality control, automatic processes, innovation and efficiency, } \\
\text { information technologies, flexibility }\end{array}$ \\
\hline $\begin{array}{l}\text { Kumar et al. } \\
\text { [27] }\end{array}$ & $\begin{array}{l}\text { Multi-objective } \\
\text { mathematical } \\
\text { programming }\end{array}$ & $\begin{array}{l}\text { Minimization of cost, minimization of late delivery, } \\
\text { minimization of inability to serve }\end{array}$ \\
\hline Ko et al. [25] & $\begin{array}{l}\text { Genetic } \\
\text { algorithms \& } \\
\text { mixed integer } \\
\text { programming }\end{array}$ & Cost minimization \\
\hline Araz et al. [28] & $\begin{array}{l}\text { Fuzzy GP \& } \\
\text { Preference } \\
\text { Ranking } \\
\text { Organization } \\
\text { Method for } \\
\text { Enrichment } \\
\text { Evaluations } \\
\text { (PROMETHEE) }\end{array}$ & $\begin{array}{c}\text { Criteria: finance, management, quality, delivery / Objectives: } \\
\text { maximization of PROMETHEE values, maximization of } \\
\text { accepted orders, maximization of on-time deliveries, } \\
\text { minimization of cost }\end{array}$ \\
\hline Yuen [12] & $\begin{array}{c}\text { Cognitive } \\
\text { Network } \\
\text { Process \& AHP }\end{array}$ & $\begin{array}{l}\text { Location, operation excellence, service quality, price } \\
\text { attractiveness }\end{array}$ \\
\hline Luk et al. [24] & Fuzzy AHP & Price, time, information technology, flexibility, reliability \\
\hline $\begin{array}{l}\text { Çelik et al. } \\
\text { [32] }\end{array}$ & $\begin{array}{c}\text { Fuzzy Grey } \\
\text { Relational } \\
\text { Analysis \& } \\
\text { Fuzzy TOPSIS }\end{array}$ & $\begin{array}{l}\text { Cooperation with customer company and its customer, green } \\
\text { government regulations, environmental management system, } \\
\text { green process design, reduction of energy consumption, green } \\
\text { network design }\end{array}$ \\
\hline Jain, Khan [33] & TOPSIS \& QFD & $\begin{array}{l}\text { Ability to collect range of product: ability to manage range of } \\
\text { product, ability to store range of product, business ethics, ability } \\
\text { to disassemble range of products, disassembly economy, } \\
\text { experience in similar products in disassembly process, green } \\
\text { policy, commitment, on time delivery, quality, network } \\
\text { coverage }\end{array}$ \\
\hline Chen et al. [34] & $\begin{array}{l}\text { Grey Incidence- } \\
\text { TOPSIS \& ANP }\end{array}$ & Service quality, service ability, alliance, cost \\
\hline
\end{tabular}


According to the literature review for the best 3PL service provider selection problem, $74 \%$ of all studies have used MCDM methods, $6 \%$ mathematical modeling techniques and $20 \%$ used other methods mentioned above. As can be seen from Table 1, while the most commonly used MCDM techniques for this problem in the literature are AHP and TOPSIS, GP is used for the simultaneous optimization of multiple objectives of the problem. This is due to the advantages of the methods mentioned in Section 2, and the focus of the literature on this group of methods is consistent with the multipurpose and multi-criteria structure of the problem. In this context, in this study, the priority values of 3PL service providers are calculated with the combination of AHP and TOPSIS by considering the criteria determined in accordance with the literature and the company facts. Then, maximization of these priority values is included in the objectives to be optimized and in line with the system constraints and other objectives specific to the company, for the first time in the literature, the best 3PL service provider-order combination (consistent with real life) list is obtained by solving the proposed a multi-objective GP model (Figure 1).

In the Section 2 of the study, the methods used in solving the problem are introduced with the reasons for use. After the detailed description of the problem and the details of the solution methodology are presented in accordance with this definition in Section 3, the study is completed with Section 4, which presents the results and recommendations of the study.

\section{METHODS}

In the literature, MCDM approaches are the most commonly used methods for the 3PL service provider selection problem as mentioned above. Among the MCDM approaches which have many examples such as AHP, ANP, TOPSIS, ELECTRE, DEMATEL and PROMETHEE, the most commonly used methods for this problem are AHP and TOPSIS (Table 1). The main reason for this is that these methods have relative advantages over others. AHP is a method which separates the problems into its components, determines the priorities of the decision makers by using their subjective evaluations and provides a hierarchical structure in line with these priorities. Other advantages of AHP are that decision-makers include assessments of criteria and alternatives at the same time, it does not seek the requirement to make certain that these evaluations and judgments are initially consistent, and that it is possible to evaluate the decision-making process and many different quantitative and qualitative factors that will affect the final outcome. The basis of TOPSIS is to determine the distance of the decision points (alternatives) from the positive and negative ideal solution and to make a ranking among these alternatives. The positive ideal solution (PIS) reflects the desired point of convergence of decision points; on the contrary, the negative ideal solution (NIS) refers to the point to be avoided. In the TOPSIS method, it is accepted that any decision point becomes closer to the PIS as it moves away from NIS, and this increases the preferability of this decision point. Furthermore, it has more simple process than the other outranking algorithms such as ELECTRE, VIseKriterijumsa Optimizacija I Kompromisno Resenje (Multicriteria Optimization and Compromise Solution - VIKOR), Simple Additive Weighting (SAW) and PROMETHEE [33-37].

Finally, GP is a multi-objective optimization method that can choose from an infinite number of alternatives. One of its advantages is that it has the capacity to handle large- scale problems. With this method, the solution of decision problems with multiple objective can be done effectively. Other advantages of the method are that it allows for loose constraints and to develop a suitable solution for infeasible results of the linear programming models. Frequently, GP combined with MCDM techniques such as AHP, TOPSIS, PROMETHEE and ANP to accommodate proper weighting. Thus, it eliminates one of its weaknesses while still being able to choose from infinite alternatives [36].

From this point of view, in this study, according to the best of our knowledge a GP model supported with AHP-TOPSIS combination (to evaluate the priority levels of the 3PL service provider) by considering the multi-criteria and multi-objective structure of the problem to determine the most appropriate order-3PL service provider combination for the first time in the literature in terms of method configuration, consistent results with real life, and considered criteria and objectives. 
The application steps of the used methods are presented in Figure 1 briefly. For detailed implementation steps of the methods, see also [38-41].

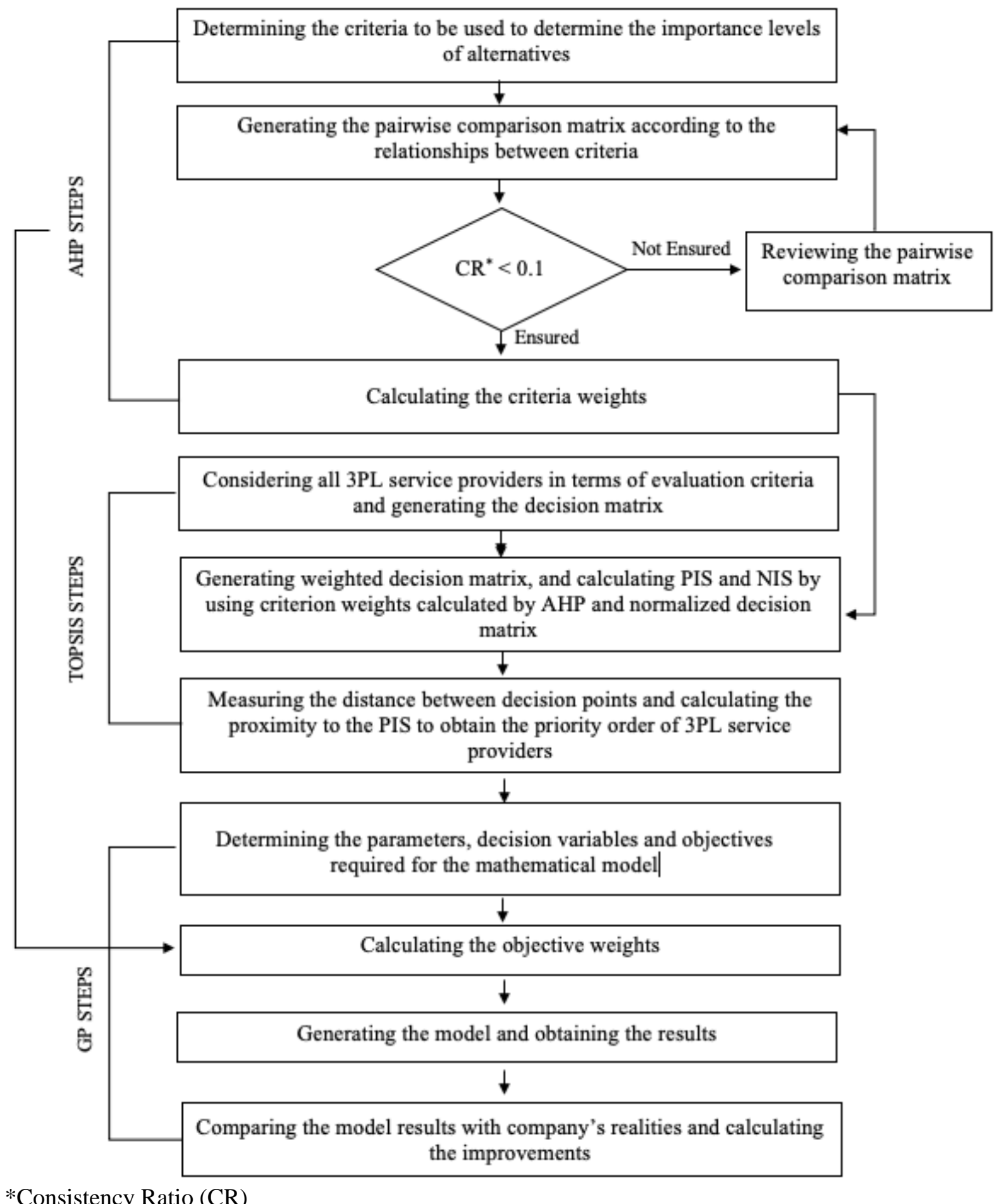

*Consistency Ratio (CR)

Figure 1. Application steps

\section{CASE STUDY}

In this study, the priority values of 3PL service providers in a foreign trade company are calculated with the combination of AHP and TOPSIS. Then, a GP model is proposed in accordance with the constraints and objectives of the company where these priority values are used for the selection of the most appropriate 3PL service provider. Using last 1-year actual data of company, the model is provided to select the most 
appropriate 3PL service provider for per order by resolving in the 12.6.2 version of the IBM ILOG CPLEX optimization software for the current 10 orders.

\subsection{Transportation Types Used in the Company's Sendings}

Type of transportation consists of express, airline, seaway and highway alternatives. The form of express delivery is most advantageous. Because, both the cost is low, and the customs process is very fast. The constraints of this transportation type are that $150 \mathrm{~kg}$ (the final weight after packed) of the gross weight of the order and the sale value is less than 7,500 Euros. If the gross weight of the order is between $150 \mathrm{~kg}$ and $400 \mathrm{~kg}$, the type of transport is the airway. When the weight is between $400 \mathrm{~kg}$ and $600 \mathrm{~kg}$, it is transported by seaway. When it is more, it is transported by highway. There is no restriction on the sales value of the order for these transportation types. In addition, only the DHL and UPS companies are able to carry out the express transport. The types of transportation (airway, seaway and highway) can perform all companies. As a result, the customer decides on the delivery method of the order.

\subsection{Description of the Problem}

The operation is done by 3PL service providers, from the factory to the delivery of the products to which it exports, in accordance with the delivery method. For each order, offers are received separately from these companies. In accordance with the offer, the company is dealt with company on the most appropriate price based on the constraints of the company. Estimated package information is sent by the manufacturer of the order whose production is about to be completed. The concept that characterizes the product variety is the weight of the order. That is, the costs vary according to the weight of the order. Offer is requested from each of the 3PL service providers based on this information. Factors related to the order that determines the offer price consist of how packages of the order, dimensions of the package together with the total weight of each package, volumetric weight and information about whether the packages are stackable. The problem will be evaluated as the weight of the order that determines the type of order and the diversity of the order reveals the size of the order. By sending this information to 3PL service providers, estimated prices and transportation plan are received e.g. if the operation is carried out by airway, the firm also transmits the flight plan. The reason for this, process can determine the transportation alternatives in advance and choose the plan that is suitable for the order. Then, the final package detail comes from the manufacturer. The final price is received from 3PL service providers according to the final package information. Moreover, due to some recent problems with the logistics companies, the company wants to comply with some constraints while making this decision. In order to comply with these constraints, the staff members in the logistics department of the company have conducted interviews with all 3PL service providers and determined the rates below:

- On-time delivery rate $>=0.5$ (delivery on time)

- Offer-invoice rate of consistency $>=0.4$ (is the same or close to the invoice amount after the shipment has been made with the offer of the logistics company)

- Problem experienced delivery rate $<=0.35$ (problems caused by the service provider in delivery)

The rate of each firm is determined for these constraints. While determining the rate in the last one year, the jobs worked with that company are taken into consideration. For example, for the delivery rate on time, 30 jobs have been done in 1 year with the company and if the number of works performed on time delivery is 15 , the rate is 0.5 . Specialist staffs aim to reduce the problems experienced by setting constraints in this way. For the last 1 year, on-time delivery, offer - invoice consistency and delivery rates of 3PL service providers are shown in Table 2. 
Table 2. Performance rates of $3 P L$ service providers

\begin{tabular}{ccccc}
\hline $\begin{array}{c}\text { 3PL Service } \\
\text { Providers }\end{array}$ & $\begin{array}{c}\text { Number of } \\
\text { Worked } \\
\text { Together }\end{array}$ & $\begin{array}{c}\text { On-time } \\
\text { Delivery Rate }\end{array}$ & $\begin{array}{c}\text { Offer - Invoice } \\
\text { Consistency } \\
\text { Rate }\end{array}$ & $\begin{array}{c}\text { Problem } \\
\text { Experienced } \\
\text { Delivery Rate }\end{array}$ \\
\hline DHL & 30 & 0.6 & 0.66 & 0.16 \\
Bolte & 18 & 0.55 & 0.61 & 0.33 \\
DSV & 19 & 0.47 & 0.57 & 0.42 \\
UPS & 5 & 0.8 & 0.5 & 0.2 \\
TNT & 3 & 0.33 & 0.33 & 0.33 \\
\hline
\end{tabular}

The system constraints in the problem addressed are summarized below:

- If the package weight is less than $150 \mathrm{~kg}$, the transportation type must be express only.

- If the order value is below 7,500 Euro, the transportation type must be express only.

- If the package weight is between 151 and $400 \mathrm{~kg}$, the transportation type must be airway.

- If the package weight is between $401-600 \mathrm{~kg}$, the transportation type must be seaway.

- If the weight of the package is more than $600 \mathrm{~kg}$, the transportation type must be highway.

- If the transportation type is express, only the companies 1 or 4 can carry.

- Each job can be assigned to only one firm.

The objectives of the problem are minimization of the cost, maximization of the timely delivery rate, maximization of the offer-invoice consistency rate, minimization of the problem experienced delivery rate and maximization of the priority values of the firms. After the order has been approved, the company requires the price of all 3PL service providers according to the order details. The company are working with 3PL service providers which is total 5 named as DHL, Bolte, DSV, UPS and TNT respectively.

In the first phase of the application, the combination of AHP and TOPSIS is used for calculating the priority levels of 3PL service providers.

\subsection{Prioritization of 3PL Service Providers}

7 criteria are determined according to the literature as well as the criteria specified by the experts in the Logistics Department in terms of the company's experience and facts. These criteria are weighted by AHP method which is frequently used in weighting problems in literature. $53 \mathrm{PL}$ service providers are prioritized using TOPSIS by using these weights. The criteria discussed in prioritization are as follows;

Speed of responding to offer request: After the orders have been approved, offer request is made from 3PL service providers. Some 3PL service providers are able to late respond to these offer requests. This criterion has been taken into account in the evaluation in order to prevent any problems in planning.

Operational performance: It is very importance for delivering the orders to customers on time. This is related to the operational performance of 3PL service providers. The better the company is well about this subject, the less the problems experienced in delivery.

Accessibility to authorized persons: Some shipments may cause problems during customs or transportation. In such cases, it is only possible to solve the problem faster with authorized persons. Therefore, the expert staff in the company wanted to take this criterion into consideration.

Company image: In this criterion, information such as how the firm dominates the market and the excess experience of similar products are taken into consideration. 
Quality: The effectiveness in management and overall performance of the 3PL service provider is taken into consideration and an evaluation is made according to this situation.

Ease of shipment at competitive prices: All 3PL service providers are required price for each approved order. One of the most important factors is to make a comeback at affordable prices of these companies.

Long term relationship: In this criterion, the communication between the 3PL service provider and the company and the information about the shipment of the company are taken into consideration. Tracking and traceability of shipments are two important factors.

Once the criteria and alternatives are determined, the AHP implementation steps are begun. Firstly, the hierarchical structure to weight the criteria affecting the priority levels of relevant 3PL service provider is formed (Figure 2). Then, the pairwise comparison matrix is created. Criteria weights are given in Table 3 and the CR is calculated as 0.023 . This means the analysis is consistent.

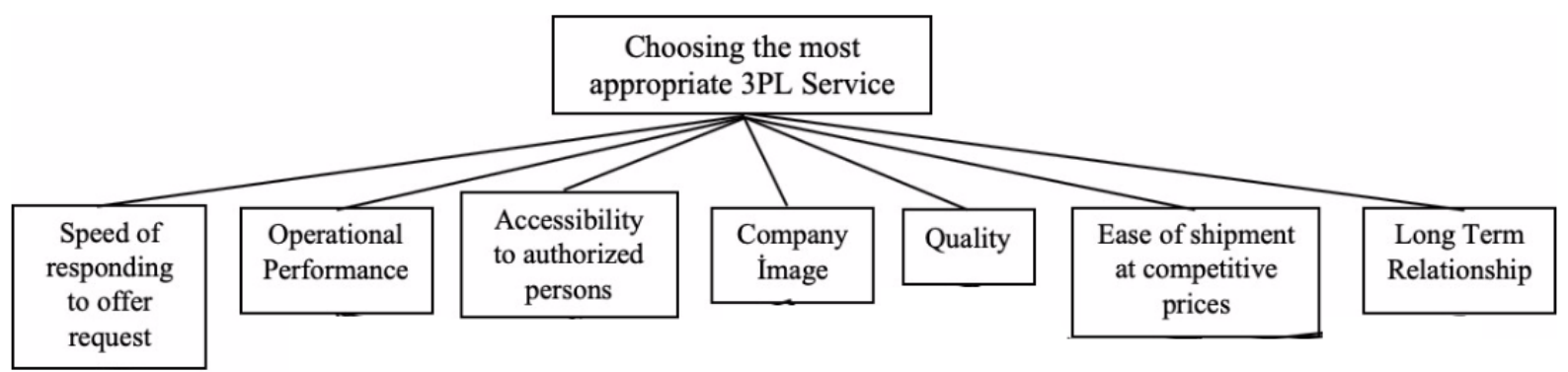

Figure 2. Hierarchical structure

Table 3. Criteria weights

\begin{tabular}{cc}
\hline Criteria & Weights \\
\hline Speed of respond to offer request & 0.0415 \\
\hline Operational performance & 0.2646 \\
\hline Accessibility to authorized persons & 0.0288 \\
\hline Company image & 0.0926 \\
\hline Quality & 0.1360 \\
\hline Ease of shipment at competitive prices & 0.3746 \\
\hline Long term relationship & 0.0620 \\
\hline
\end{tabular}

These criteria weights calculated by AHP are used in the prioritization phase of 3PL service providers by TOPSIS. First, the values of the criteria and the decision matrix of each alternative are established and given in Table 4.

The decision matrix given in Table 4 and the weights of criteria given in Table 3 are applied to the application steps given in Figure 1 and the priority levels of each service provider are calculated and given in Table 5. 
Table 4. Decision matrix

\begin{tabular}{|c|c|c|c|c|c|c|c|}
\hline \multirow[b]{2}{*}{ 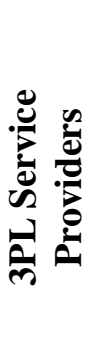 } & \multicolumn{7}{|c|}{ Criteria } \\
\hline & 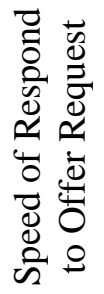 & 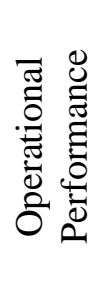 & 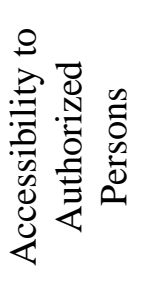 & 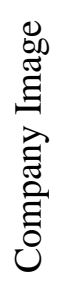 & $\begin{array}{l}\stackrel{\vec{\Xi}}{\sigma} \\
\stackrel{\tilde{\partial}}{\partial}\end{array}$ & 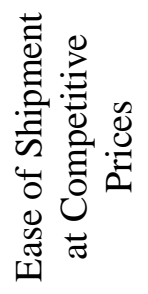 & 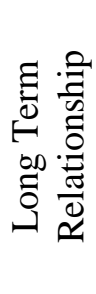 \\
\hline DHL & 7 & 3 & 5 & 8 & 9 & 10 & 8 \\
\hline Bolte & 3 & 7 & 6 & 4 & 5 & 8 & 3 \\
\hline DSV & 5 & 5 & 3 & 1 & 4 & 9 & 2 \\
\hline UPS & 9 & 10 & 8 & 6 & 7 & 6 & 5 \\
\hline TNT & 6 & 9 & 1 & 2 & 6 & 4 & 4 \\
\hline
\end{tabular}

Table 5. Priority levels of the $3 P L$ service providers

\begin{tabular}{cc}
\hline $\begin{array}{c}\text { Calculation of Proximity according to Ideal } \\
\text { Solution }\end{array}$ & 3PL Service Provider \\
\hline 0.5759 & DHL \\
\hline 0.5578 & Bolte \\
\hline 0.4877 & DSV \\
\hline 0.5952 & UPS \\
\hline 0.4075 & TNT \\
\hline
\end{tabular}

\subsection{Weighted GP Solution}

At this stage, the problem of assigning 5 3PL service provider to 10 orders is modelled by minimization of cost, maximization of the on-time delivery rate, maximization of the problem invoice consistency, maximization of problematic delivery rate and maximization of priority levels of the service providers. In the weighted goal programming method, each objective must have a weight. Therefore, expert staff gave value to each objective in the range of 1 to 10 according to the company's and the sector's realities. For weighting the objectives, AHP is used again and the CR of objectives pairwise comparison matrix is calculated as 0.021 . According to this consistent analysis, calculated objective weights are given in Table 6.

Table 6. Objectives' weights

\begin{tabular}{lc}
\hline \multicolumn{1}{c}{ Objectives } & Weights \\
\hline Cost minimization & 0.27 \\
\hline Maximization of on-time delivery rate & 0.22 \\
\hline Maximizing the offer-invoice consistency rate & 0.13 \\
\hline Minimization of problematic delivery rate & 0.19 \\
\hline Maximizing priority values & 0.19 \\
\hline
\end{tabular}

According to the problem definition given in Section 3.2, proposed GP model is presented below: 


\section{$\underline{\text { Notations }}$}

$k_{i}=i^{\text {th }}$ order weight $(\mathrm{kg})$

$i=1,2, \ldots, 10$

$q_{i}=$ sales value of $i^{\text {th }}$ order $(€)$

$i=1,2, \ldots, 10$

$c_{i j k}=$ the price for $k^{\text {th }}$ type of transportation of $j^{\text {th }}$ company to $i^{\text {th }}$ order

$i=1,2, \ldots, 10 ; j=1,2, \ldots, 5 ; k=1,2,3,4$

$z_{j}=$ on-time delivery rate of $j^{\text {th }}$ company

$t_{j}=j^{\text {th }}$ company's offer - invoice consistency rate

$p_{j}=$ delivery rate of the $j^{\text {th }}$ company experienced problem

$j=1,2, \ldots, 5$

$j=1,2, \ldots, 5$

$a_{j}=j^{\text {th }}$ company's priority values

$j=1,2, \ldots, 5$

$W_{l}=$ weighting of the $l^{\text {th }}$ objective calculated by AHP

$j=1,2, \ldots, 5$

$d_{l}=$ level below of $l^{\text {th }}$ objective value

$l=1,2, \ldots, 5$

$d_{l}^{+}=$exceeding level of the $l^{\text {th }}$ objective value

$l=1,2, \ldots, 5$

$l=1,2, \ldots, 5$

$x_{i j k}=\left\{\begin{array}{cc}1 & i^{\text {th }} \text { order the } k^{\text {th }} \text { realization status with type of transportation of } j^{\text {th }} \text { company } \\ 0 & \text { otherwise } \\ i=1,2, \ldots, 10 ; j=1,2, \ldots, 5 ; k=1,2,3,4\end{array}\right.$

\section{Objective Function}

1. Cost minimization $\left(W_{l}=0.27\right)$

2. Maximization of on-time delivery rate $\left(W_{2}=0.22\right)$

3. Maximizing the offer-invoice consistency rate $\left(W_{3}=0.13\right)$

4. Minimization of problem experienced delivery rate $\left(W_{4}=0.19\right)$

5. Maximizing of companys' priority values $\left(W_{5}=0.19\right)$

$\operatorname{Min} Z=W_{1} * d_{1}{ }^{+}+W_{2} * d_{2}{ }^{-}+W_{3} * d_{3}{ }^{-}+W_{4} * d_{4}{ }^{+}+W_{5} * d_{5}{ }^{-}$

\section{$\underline{\text { Constraints }}$}

1. If the package weight is $150 \mathrm{~kg}$ and the order value is below 7,500 Euro, the transportation type must be express only.

$$
\begin{array}{ll}
\forall i=1,2, \ldots, 10 & k_{i} \sum_{j=1}^{5} x_{i j 1} \leq 150 \\
\forall i=1,2, \ldots, 10 & q_{i} \sum_{j=1}^{5} x_{i j 1} \leq 7,500
\end{array}
$$

2. When the package weight is between 151 and $400 \mathrm{~kg}$, the transportation type must be airway.

$$
\begin{array}{ll}
\forall i=1,2, \ldots, 10 & k_{i} \sum_{j=1}^{5} x_{i j 2} \geq 151 \\
\forall i=1,2, \ldots, 10 & k_{i} \sum_{j=1}^{5} x_{i j 2} \leq 400
\end{array}
$$

3. If the package weight is between $401-600 \mathrm{~kg}$, the transportation type must be seaway.

$$
\begin{array}{ll}
\forall i=1,2, \ldots, 10 & k_{i} \sum_{j=1}^{5} x_{i j 3} \geq 401 \\
\forall i=1,2, \ldots, 10 & k_{i} \sum_{j=1}^{5} x_{i j 3} \leq 600
\end{array}
$$

4. If the package weight is more than $600 \mathrm{~kg}$, the transportation type must be highway.

$$
\forall i=1,2, \ldots, 10 \quad k_{i} \sum_{j=1}^{5} x_{i j 4} \geq 601
$$

5. If the type of transport is express, only the companies 1 or 4 can carry.

$$
\forall i=1,2, \ldots, 10 \quad x_{i 11}+x_{i 41}=1
$$

6. Each job can be assigned to only one firm.

$$
\forall i=1,2, \ldots, 10 \quad \sum_{j=1}^{5} \sum_{k=1}^{4} x_{i j k}=1
$$

7. Minimization of cost target constraint

$$
\sum_{i=1}^{10} \sum_{j=1}^{5} \sum_{k=1}^{4} c_{i j k} * x_{i j k}+d_{l}^{-}-d_{l}^{+}=8,000
$$

8. Maximizing of the delivery rate on time target constraint

$$
\sum_{j=1}^{5} z_{j} \sum_{i=1}^{10} \sum_{k=1}^{4} x_{i j k}+d_{2}{ }^{-}-d_{2}{ }^{+}=5
$$


9. Maximizing of offer - invoice consistency rate target constraint $\sum_{j=1}^{5} t_{j} \sum_{i=1}^{10} \sum_{k=1}^{4} x_{i j k}+d_{3}{ }^{-}-d_{3}{ }^{+}=4$

10. Minimization of problematic delivery rate target constraint $\sum_{j=1}^{5} p_{j} \sum_{i=1}^{10} \sum_{k=1}^{4} x_{i j k}+d_{4}{ }^{-}-d_{4}{ }^{+}=3.5$

11. Maximizing of priority values objective constraint $\sum_{j=1}^{5} a_{j} \sum_{i=1}^{10} \sum_{k=1}^{4} x_{i j k}+d_{5}-d_{5}{ }^{+}=1$

12. $d_{j}^{+}, d_{j}^{-} \geq 0$

$$
x_{i j k}=0 \text { or } 1
$$

The proposed model is solved by using the company's last one-year data, the most appropriate 3PL service provider for each order is specified in the IBM ILOG CPLEX optimization software for 5 orders, 210 decision variables and 12 constraints under 1 minute available for 10 pcs order. The results obtained as a result of the solution of the model are shown in Table 7 below.

Table 7. Results of the model

\begin{tabular}{ccc}
\hline $\begin{array}{c}\text { Order } \\
\text { Number }\end{array}$ & $\begin{array}{c}\text { Specified 3PL Service } \\
\text { Provider }\end{array}$ & $\begin{array}{c}\text { Specified Type of } \\
\text { Transportation }\end{array}$ \\
\hline 1 & UPS & Express \\
\hline 2 & Bolte & Airway \\
\hline 3 & UPS & Express \\
\hline 4 & Bolte & Airway \\
\hline 5 & UPS & Express \\
\hline 6 & UPS & Express \\
\hline 7 & Bolte & Highway \\
\hline 8 & Bolte & Airway \\
\hline 9 & UPS & Express \\
\hline 10 & Bolte & Highway \\
\hline & & 1,81 \\
\hline Objective Function Value & \\
\hline
\end{tabular}

The smallness of the obtained objective function value and deviation variables shows that the result of the model is consistent. In order to minimize the cost and minimize the delivery rate, the deviation variable is calculated as " 0 ", which means that the objectives are fully realized. There was a deviation of 5 units while maximizing on-time delivery rate, 4 units while maximizing offer-invoice consistency ratio and 1 unit while maximizing priority values.

The company assigns orders to service providers only on the basis of cost in real life. In this case, the performance of the service providers is ignored. With this study, the most effective method that takes into account the performance of service providers is determined and the cost is minimized. Performance criteria are discussed, and a more analytic result is obtained by using AHP-TOPSIS combination. The determination of more than one objective in the problem and the different importance of these objectives made it necessary to use GP, one of the multi-objective optimization approaches. As a result of the solution of the problem with this method combination, improvements of $7 \%$ on-time delivery, $33 \%$ on offer - invoice consistency rate, and $29 \%$ on problematic delivery rate is achieved. 


\section{CONCLUSION AND RECOMMENDATIONS}

Logistics for companies is one of the most important cost factors and there are many important decision criteria during the selection decision of the 3PL service provider. Therefore, it is very important to choose the methods and algorithms to be used when making this decision. On the basis of all these importance factors, the first time in the literature, a model that demonstrates the results of multimodal international transportation in the transportation sector is proposed, and it is aimed to select the most appropriate 3PL service provider based on the orders of the company being discussed.

In this respect, firstly, AHP-TOPSIS combination was used by aim to determine the level of importance of the 3PL service providers AHP method for the evaluation separately contribution to the main target of all the criteria and the TOPSIS method to make the best choice among the alternatives. 3PL service providers have been selected on the basis of order by resolving the model for the current 10 orders, offering multipurpose weighted goal programming model aimed at maximizing these priority values, minimizing cost, maximizing delivery rate, minimizing problematic delivery rate and maximizing offer-invoice consistency rate.

As a result of the problem discussed, the reason for cannot commenting improvement on the cost item is that the price of 3PL service providers varies depending on the order weight of each order. In other words, when the weight of the order increases, the cost will increase and in the same way decrease of the weight of order will decrease the cost again. In order to comment on the cost, the orders with the same weight and volume should be assigned. However, due to the realization of the real situation of the company, the realization of the order-based sales and the specific weight and volume of each order, a cost-related improvement rate cannot be given. Considering the improvements, these remarkable findings for the company, in addition to the consistency of the established model, it is seen that 3PL service provider selection contributed to the literature. As the company develops an order-based sales strategy for this problem, orders cannot be divided, and each customer is sent to according to the order. However, considering the future studies by expanding the content of the problem, The aim is to eliminate the lack of literature and to provide more analytical results (Such as determination of supplier and order quantity to be assigned). Due to the fact that it can work with integer, adapt to multi-purpose problems, determine priority values, and break the subjectivity coming from AHP and TOPSIS, it is recommended to solve the problem with Constraint Programming.

\section{CONFLICTS OF INTEREST}

No conflict of interest was declared by the authors.

\section{REFERENCES}

[1] Rantasila, K. and Lauri, O., "Measurement of National-Level Logistics Costs and Performance", ITF Discussion Paper, No.2012-4:10-14, (2012).

[2] National Skills Development Corporation (NSDC). Human Resource and Skill Requirements Report (2017-22): https://www.voced.edu.au/content/ngv\%3A78369, (2018).

[3] Aguezzoul, A. and Pires, S., "3PL performance evaluation and selection: A MCDM method", Suppl. Ch. Forum Int. J., 17(2): 87-94, (2016).

[4] Ahıskalı, M., "A Goal Programming Model Supported with Multi-Criteria Decision Making Approachs for Third Party Logistics Service Provider Selection Problem", M.Sc.Thesis, Kirıkale University, Kırıkkale, 10-15, (2018).

[5] Göl, H. and Çatay, B., "Third-party logistics provider selection: insights from a Turkish automotive company", Suppl. Ch. Manage. Int. J., 12(6): 379-384, (2007). 
[6] Soh, S.H., "A decision model for evaluating third-party logistics providers using fuzzy analytic hierarchy process", Afr. J. Bus. Manage., 4(3): 339-349, (2010).

[7] Vijayvargiya, A. and Dey, A.K., "An analytical approach for selection of a logistics provider", Manage. Decis., 48(3): 403-418, (2010).

[8] Barker, T.J. and Zabinsky, Z.B., "A multicriteria decision making model for reverse logistics using analytical hierarchy process", Omega, 39(5): 558-573, (2011).

[9] Daim, T.U., Udbye, A. and Balasubramanian, A., "Use of analytic hierarchy process (AHP) for selection of 3PL providers", J. Manuf. Techn. Manage., 24(1): 28-51, (2012).

[10] Hwang, B., Chen, T. and Lin, J., "3PL selection criteria in integrated circuit manufacturing industry in Taiwan”, Suppl. Ch. Manage. Int. J., 21(1): 103-124, (2016).

[11] Gürcan, Ö.F., Yazıcı, İ., Beyca, Ö.F., Arslan, Ç.Y. and Eldemir, F., “Third party logistics (3PL) provider selection with AHP application”, Proc. Soc. Behav. Sci., 235(1): 226-234, (2016).

[12] Yuen, K.K.F., "Towards Logistics Service Provider Selection Strategy Using Primitive Cognitive Network Process", $10^{\text {th }}$ International Conference on Service Systems and Service Management, Hong Kong, 416-418, (2013).

[13] Jharkharia, S. and Shankar, R., "Selection of logistics service provider: an analytic network process (ANP) approach", Omega, 35(3): 274-289, (2007).

[14] Özbek, A. and Eren, T., "Selection of third-party logistics (3PL) firms with analytical network process approach”, Atatürk Üni. J. Econ. Admin. Sci., 27(1): 95-113, (2013).

[15]Qureshi, M.N., Kumar, D. and Kumar, P., "Selection of Potential 3PL Services Providers Using TOPSIS with Interval Data", IEEE International Conference on Industrial Engineering and Engineering Management, Singapore, 1512-1516, (2007).

[16] Aguezzoul, A., Rabenasoloo, B. and Jolly-Desodt, A.M., "Multicriteria Decision Aid Tool for ThirdParty Logistics Providers' Selection", International Conference Service Systems and Service Management (ICSSSM), France, 912-916, (2006).

[17] Govindan, K., Khodaverdi, R. and Vafadarnikjoo, A., "A grey DEMATEL approach to develop thirdparty logistics provider selection criteria”, Ind. Manage. Data. Sys.,116(4): 690-722, (2015).

[18] Kulak, O. and Kahraman, C., "Fuzzy multi-attribute selection among transportation companies using axiomatic design and analytic hierarchy process", Infor. Sci., 170(2): 191-210, (2005).

[19] Bottani, E. and Rizzi, A., "A fuzzy TOPSIS methodology to support outsourcing of logistic services", Suppl. Ch. Manage. Int. J., 11(4): 294-308, (2006).

[20] Kasture, S.S., Qureshi, M.N., Kumar, P. and Gupta, I., "FAHP sensitivity analysis for selection of third party logistics (3PL) service providers", The Icfai Uni. J. Suppl. Ch. Manage., 5(4): 41-60, (2008).

[21] Çakır, E., Tozan, H. and Vayvay, O., "A method for selecting third party logistic service provider using fuzzy AHP”, J. Nav. Sci. Eng., 5(3): 38-54, (2009).

[22] Chiang, Z. and Tzeng, G.H., "A third party logistics provider for the best selection in fuzzy dynamic decision environments", Int. J. Fuzz. Sys., 11(1): 1-9, (2009). 
[23] Yayla, A.Y., Öztekin, A., Gümüş, A.T. and Gunasekaran, A.A., "Hybrid data analytic methodology for 3PL ransportation provider evaluation using fuzzy multi-criteria decision making", Int. J. Prod. Res., 53(20): 6097-6113, (2015).

[24] Luk, C.C., Choy, K.L. and Lam, H.Y., "Design of an Enhanced Logistics Service Provider Selection Model for e-Commerce Application", Portland International Conference on Management of Engineering and Technology (PICMET), Honolulu, 1-7, (2018).

[25] Ko, H.J., Ko, C.S. and Kim, T., "A hybrid optimization/simulation approach for a distribution network design of 3PLs”, Compt. Ind. Eng., 50(4): 440-449, (2006).

[26] Sharma, S.K. and Kumar, V., "Optimal selection of third-party logistics service providers using quality function deployment and Taguchi loss function”, Benchmarking Int. J., 22(7): 1281-1300, (2014).

[27] Kumar, M., Vrat, P. and Shankar, R., "A multi-objective 3PL allocation problem for fish distribution", Int. J. Phys. Distrib. Logist Manage., 36(9): 702-715, (2006).

[28] Araz, C., Özfirat, P.M. and Özkarahan, I., "An integrated multicriteria decision-making methodology for outsourcing management”, Compt. Opera. Res., 34(12): 3738-3756, (2007).

[29] Perçin, S., "Evaluation of third-party logistics (3PL) providers by using a two-phase AHP and TOPSIS methodology”, Benchmarking Int. J., 16(5): 588-604, (2009).

[30] Raut, R., Kharat, M., Kamble, S. and Kumar, C.S., "Sustainable evaluation and selection of potential third-party logistics (3PL) providers an integrated MCDM approach", Benchmarking Int. J., 25(1): 7697, (2018).

[31] Bianchini, A., "3PL provider selection by AHP and TOPSIS methodology", Benchmarking Int. J., 25(1): 235-252, (2018).

[32] Çelik, E., Erdoğan, M. and Gümüş, A.T., “An extended fuzzy TOPSIS-GRA method based on different separation measures for green logistics service provider selection", Int. J. Environ. Sci. Technol., 13: 1377-1396, (2016).

[33] Jain, V. and Khan, S.A., "Reverse Logistics Service Provider Selection: A TOPSIS-QFD Approach", IEEE International Conference on Industrial Engineering and Engineering Management, Bali, 803806, (2016).

[34]Chen, K., Yu, X. and Yang, L., "GI-TOPSIS based on combinational weight determination and its application to selection of reverse logistics service providers", J. Grey. Sys., 25(3): 16-33, (2013).

[35] Singh, R.K., Gunasekaran, A. and Kumar, P., "Third party logistics (3PL) selection for cold chain management: a fuzzy AHP and fuzzy TOPSIS approach”, Ann. Oper. Res., 267(1-2): 531-553, (2017).

[36] Velasquez, M. and Hester, P.T., “An analysis of multi-criteria decision making methods”, Int. J. Opera. Res., 10(2): 56-66, (2013).

[37] Özcan, E.C., Ünlüsoy, S. and Eren, T., "A combined goal programming - AHP approach supported with TOPSIS for maintenance strategy selection in hydroelectric power plants", Renew. Sustain. Energy Rev., 78: 1410-1423, (2017).

[38] Saaty, T.L., "Decision making with the analytic hierarchy process", Int. J. Serv. Sci., 1(1): 83-98, (2008). 
[39] Hwang, C.L. and Yoon, K., Multiple Attribute Decision Making: Methods and Applications, SpringerVerlag, New York, (1981).

[40] Saaty, T.L., "How to make a decision: the analytic hierarchy process", Eur. J. Opera. Res., 48:9-26, (1990).

[41]Charnes, A. and Cooper, W.W., "Goal programming and multiple objective optimizations", Eur. J. Opera. Res., I:39-54, (1977). 